Short communication

\title{
Cage fish farm act as a source of changes in the fish community of a Neotropical reservoir
}

\author{
André Batista Nobile ${ }^{a, *}$, Augusto Seawright Zanatta ${ }^{\mathrm{b}}$, Heleno Brandão ${ }^{\mathrm{c}}$, Zica E.O.P. ${ }^{\mathrm{d}}$, Lima F.P. ${ }^{\mathrm{a}}$, \\ Diogo Freitas-Souza ${ }^{\mathrm{a}}$, Edmir Daniel Carvalho ${ }^{\mathrm{a}}$, Reinaldo José da Silva ${ }^{\mathrm{d}, \mathrm{f}}$, Igor Paiva Ramos ${ }^{\mathrm{e}, \mathrm{f}}$ \\ ${ }^{a}$ Universidade Estadual Paulista (UNESP), Instituto de Biociências, Câmpus Botucatu, Departamento de Morfologia, SP, Brazil \\ ${ }^{\mathrm{b}}$ Universidade Estadual do Norte do Paraná (UENP), Campus de Cornélio Procópio, Laboratório da Vida Aquática (LaVidA), PR160, KM 0, CEP 86300-000, Cornélio \\ Procóprio, PR, Brazil \\ ${ }^{\mathrm{c}}$ Universidade Tecnológica Federal do Paraná - UTFPR Câmpus Santa Helena, Prolongamento da Rua Cerejeira, s/n, CEP 85892-000 Bairro São Luiz - Santa Helena, PR, \\ Brazil \\ d UNESP - Universidade Estadual Paulista, Câmpus de Botucatu, Instituto de Biociências, Departamento de Parasitologia, Botucatu, São Paulo, Brazil \\ e Universidade Estadual Paulista (UNESP), Faculdade de Engenharia de Ilha Solteira, Câmpus Ilha Solteira, Departamento de Biologia e Zootecnia, SP, Brazil \\ ${ }^{\mathrm{f}}$ Universidade Estadual Paulista (UNESP), Instituto de Biociências, Câmpus Botucatu, Programa de Pós-graduação em Ciências Biológicas - Zoologia, SP, Brazil
}

\section{A R T I C L E I N F O}

\section{Key-words:}

Aquaculture influence

Fish communities

Diversity

Richness

Paranapanema River

\begin{abstract}
A B S T R A C T
Brazil has shown an increase in cage fish farms activity in reservoirs. However, this activity shows potential to cause several changes in the environment with consequences in the structure of native fish fauna community. Thus, the hypothesis of this work is that three cage fish farms, located in the different areas of Chavantes reservoir, high Paraná basin, have potential to interfere with resident fish communities, modifying their structure. Fish were caught in twelve monthly field samplings around three cage fish farms (FF) (FF1 and FF2 Dec/06-Nov/07; FF3 - Mar/08-Feb/09) and their respective reference sites (RF) (RF1, RF2 and RF3), using gillnets with 3 to $14 \mathrm{~cm}$ between opposite knots. Our data showed that cage fish farms cause increase in fish abundance and biomass around cages. However, Margalef Richness and Shannon-Wiener diversity decreased in these areas. Spatially, fish community around cage fish farms differed from those observed in the reference sites (Permanova two-way: $(\mathrm{F}=12.747 ; \mathrm{p}=0.001)$ ). However, seasonal differences were not observed $(\mathrm{F}=1.3732$; $\mathrm{p}=0.089$ ). This difference was illustrated by NMDS, that showed the formation of two groups, one composed by fish farms and another by reference sites. These differences were mainly influenced by a small group of fish species (Apareiodon affinis, Steindachnerina insculpta (detritivores) and Pimelodus maculatus (generalist) (Simper analysis)) that are able to consume wastes released. We conclude that the cage fish farm act as a driver of alterations in the fish community, increasing the abundance and biomass of a few species which contributes to decrease Richness and Diversity.
\end{abstract}

\section{Introduction}

In recent decades, human population growth has caused an increase in resource demand, among them food and electricity. This fact lead to an increase in electricity generation through the construction of new hydropower plants instead of other forms of electricity generation (Zarfl et al., 2015), and in the Upper Paraná River basin has approximately 130 hydropower plants (Agostinho et al., 2008). Reservoirs created by a river damming, despite of generate electricity, are used to produce aquatic organisms for food (Agostinho et al., 2007; FAO, 2016).

Brazil has one of the most favorable potential for freshwater aquaculture, with $12 \%$ of world available freshwater and an area of 5.5 million of hectares in public reservoirs (Bueno et al., 2015; Lima et al., 2016). This scenario, aligned with large federal investment since the end of 1990's (Bueno et al., 2015) and the encouragement of the substitution of exploratory fisheries for aquaculture (Pelicice et al., 2014), contributed for an intense growth of this activity in Brazil. As result, Brazilian aquaculture produced, in 2015, R\$ 4.39 billion of which, $69 \%$ from fish farming. In the freshwater aquaculture, Oreochromis niloticus follows as the main specie, accounting for $45.9 \%$ of the total produced, with 220 thousand tons (IBGE, 2015).

Historically, river damming has induced impacts like restructuring of fish communities (Araújo et al., 2013), depletion of rheophilic fishes,

\footnotetext{
* Corresponding author at: Universidade Estadual Paulista (UNESP), Instituto de Biociências, Câmpus Botucatu, Departamento de Morfologia, SP, Brazil

E-mail addresses: andrenobile@hotmail.com, andrenobile@ibb.unesp.br (A.B. Nobile).
} 
proliferation of small and sedentary species (Agostinho et al., 2007; Nobile et al., 2016) and introduction of non-native fish species (Gois et al., 2015). Further, the recent expansion of aquaculture in cage fish farms can act as a new source to impact fish communities in large reservoirs in Neotropical region (Brandão et al., 2014; Brandão et al., 2013; Brandão et al., 2012; Ramos et al., 2013).

The release of organic matter in the environment, is one of the most common impacts of this activity (Pillay, 2004). This organic matter often causes environmental changes, as water eutrophication with increase in primary production (Miranda et al., 2016; Price et al., 2015) and loss in benthic fauna richness (Tomassetti et al., 2016). Over the ichthyofauna, in marine environment large aggregation of fish around cage fish farms was extensively observed (Bacher et al., 2012; Dempster and Sanchez-Jerez, 2004; Dempster et al., 2002; Özgül and Angel, 2013). In freshwater ecosystem, a few studies performed also have related aggregations of fish around cages (Brandão et al., 2012; Demétrio et al., 2012; Ramos et al., 2013; Strictar-Pereira et al., 2010), despite of the mainly focus of these studies be feed interactions. In both environments, food and protection are the most commons attractiveness driver. The physical structure can act as fish aggregation device (FAD), providing shelter for attracted populations, however, due to the continuous input of food, this structure does not act as conventional FAD's (Dempster et al., 2002; Sanchez-Jerez et al., 2011).

This aggregation can affect fish fauna by restructuring animal communities, favoring a few species (Bartozek et al., 2014; Dempster and Sanchez-Jerez, 2004; Loureiro et al., 2011; Menezes and Beyruth, 2003), improving fishing pressure in the vicinity (Akyol and Ertosluk, 2010; Bagdonas et al., 2012) or altering their diet and populational attributes (Brandão et al., 2013; Brandão et al., 2012; Ramos et al., 2013). However, most of studies were performed in marine environments (Bacher et al., 2012; Dempster and Sanchez-Jerez, 2004; Dempster et al., 2002; Izquierdo-Gomez et al., 2015; Machias et al., 2005; Machias et al., 2004; Özgül and Angel, 2013; Sanchez-Jerez et al., 2011). The scientific literature for freshwater environment focusing in the reorganization of fish community is limited, being that the most of studies focus in the diet (Brandão et al., 2013; Brandão et al., 2012; Demétrio et al., 2012; Ramos et al., 2013; Ramos et al., 2008; StrictarPereira et al., 2010). In this way, the effects of the cultivation of $O$. niloticus in cage fish farm on native biota are still poorly elucidated.

Thus, the aim of this paper was to evaluate the influence of $O$. niloticus cage fish farms on the native fish community in a Neotropical reservoir. Specifically, we tried to answer the following questions: a) can the cage fish farm activity in a freshwater environment modify the composition and structure of the native fish community? b) which fish species or trophic guild are most influenced in this environment?

\section{Materials and methods}

\subsection{Study area}

The study was performed around three different sampling areas with cage fish farms, located in the Chavantes Reservoir, Paranapanema River, where the main cultured species is O. niloticus (Fig. 1). The Chavantes Reservoir is a storage dam with a remarkably dendritic morphology and is the second of a series of 11 cascade reservoirs in the Paranapanema axis, formed by the junction of the Paranapanema and Verde Rivers (Montanhini et al., 2015). Situated approximately $480 \mathrm{~m}$ above sea level, between São Paulo and Paraná States, it has a surface area of $400 \mathrm{~km}^{2}$, mean and maximum depths of 22 and $89 \mathrm{~m}$, respectively, with a total volume of $9.410 \times 10^{6} \mathrm{~m}^{3}$ and a total discharge of $3.252 \mathrm{~m}^{3} / \mathrm{s}$, a retention time of 352 days and an oligotrophic state (historical data: total phosphorus: $31.36 \pm 7.85 \mathrm{mg} / \mathrm{m}^{-3}$; total nitrogen $0.80 \pm 0.22 \mathrm{~g} / \mathrm{m}^{-3}$ ) (Montanhini et al., 2015).

In each sampling areas, fishes were caught in two different locations: one location is at the fish farm (FF1, FF2 and FF3), and another upstream from fish farms, named Reference (RF1, RF2 and RF3). In all sampling areas, the reference site was located upstream of the fish farm, where there was no influence from this activity (Fig. 1). The environmental characteristics and localization of the fish farms are shown in Table 1.

\subsection{Sampling procedure}

For fish collection (IBAMA/ICMBio license: 15549-1), a set of gillnets with a mesh size from 3 to $14 \mathrm{~cm}$ between opposite knots were installed among the cage line in each fish farm and, in a reference site, with standardized effort. Number, length and height of gillnets used in each sampling site are shown in Table S1. Gillnets were exposed from sunset (approximately 04:00 pm) to dawn (approximately 08:00 am) for 16 h. Samplings were carried out monthly from Dec/2006 to Nov/2007, in the fish farms and reference sites 1 and 2 and from Mar/2008 to Feb/ 2009 in the fish farm and reference site 3 . All individuals caught with gillnets were grouped into a single sample per sample site. Each individual caught with gillnet was counted, measured $(\mathrm{cm})$ and weighted ( $g$ ) for estimation of abundance and biomass. Fishes were identified with specific keys (Britto et al., 2003; Graça and Pavanelli, 2007).

\subsection{Statistical analysis}

Three analyses were conducted in Primer software (Plymouth Routines Multivariate Ecological Research), version 6.0 (Clarke and Warwick, 2001): a two-way Permutational Multivariate Analysis of Variance (PERMANOVA) with Monte-Carlo test (999 permutations), to verify possible differences in species composition between communities of each sample area, considering seasonal effects. A Non-Metric Multidimensional Scaling (NMDS), to demonstrate graphically the distance matrices between areas and Similarity Percentages analysis (SIMPER), to verify which fish species more contributed to the differences between areas. For the two first analyses, data were transformed (square root) and a resemblance matrix of Bray-Curtis were generated. In this matrix, months are considered as replicates of each sample area and two factors are used "site" and "season" to contemplate spatial and seasonal trends.

Additionally, monthly values for each sampling site for abundance, biomass, Margalef Richness and Shannon-Wiener Diversity was obtained in Past 3.0 (Hammer et al., 2001). To test significant differences among sites, as values of Margalef and Shannon had non-normal distribution, a Man-Whitney test was performed. For abundance and biomass, due to high monthly variation of data, a $\mathrm{Z}$ test was performed, to avoid misinterpretation. Also, to evaluate ecological patterns, comparisons were made between all fish farm and all reference sites for all analysis (FF1xRF1, FF1xRF2, FF1xRF3, FF2xRF1, FF2xRF2, FF2xRF3, FF3xRF1, FF3xRF2 and FF3xRF3).

\section{Results}

Considering all sample areas, a total of 9252 individuals, belonging to four orders, 17 families and 46 species, with total weight of $774.27 \mathrm{~kg}$, were caught. Except by abundance in FF1, Fish Farm (FF) areas had higher and significant values of abundance and biomass than Reference Site (RF): (Abundance: $\mathrm{RF} 1=1087 ; \quad \mathrm{FF} 1=773$; $\mathrm{RF} 2=1021 ; \quad \mathrm{FF} 2=1355 ; \quad \mathrm{RF} 3=1110 ; \quad \mathrm{FF} 3=3906) \quad$ (Biomass: $\mathrm{RF} 1=73.92 \mathrm{~kg} ; \mathrm{FF} 1=104.44 \mathrm{~kg} ; \mathrm{RF} 2=69.05 \mathrm{~kg} ; \mathrm{FF} 2=158.20 \mathrm{~kg}$; RF3 $=76.76$; FF3 $=261.90 \mathrm{~kg}$ ) (Table S2, Fig. 2). Margalef Richness and Shannon-Wiener Diversity also showed significant differences, however with higher values in Reference Site in all analyzed areas (Fig. 2, Table S3).

These differences promote alterations in the community structure between sample areas, as showed by PERMANOVA ( $\mathrm{F}=12.747$; $\mathrm{p}$ (Monte-Carlo test $)=0.001)$. However, for seasonal analysis, this difference was not observed $(\mathrm{F}=1.3732$; $\mathrm{p}$ (Monte-Carlo test) $=0.089$ ) (Table S4). The non metric multidimensional scaling (NMDS), illustrates graphically this difference, with the formation of two distinct 


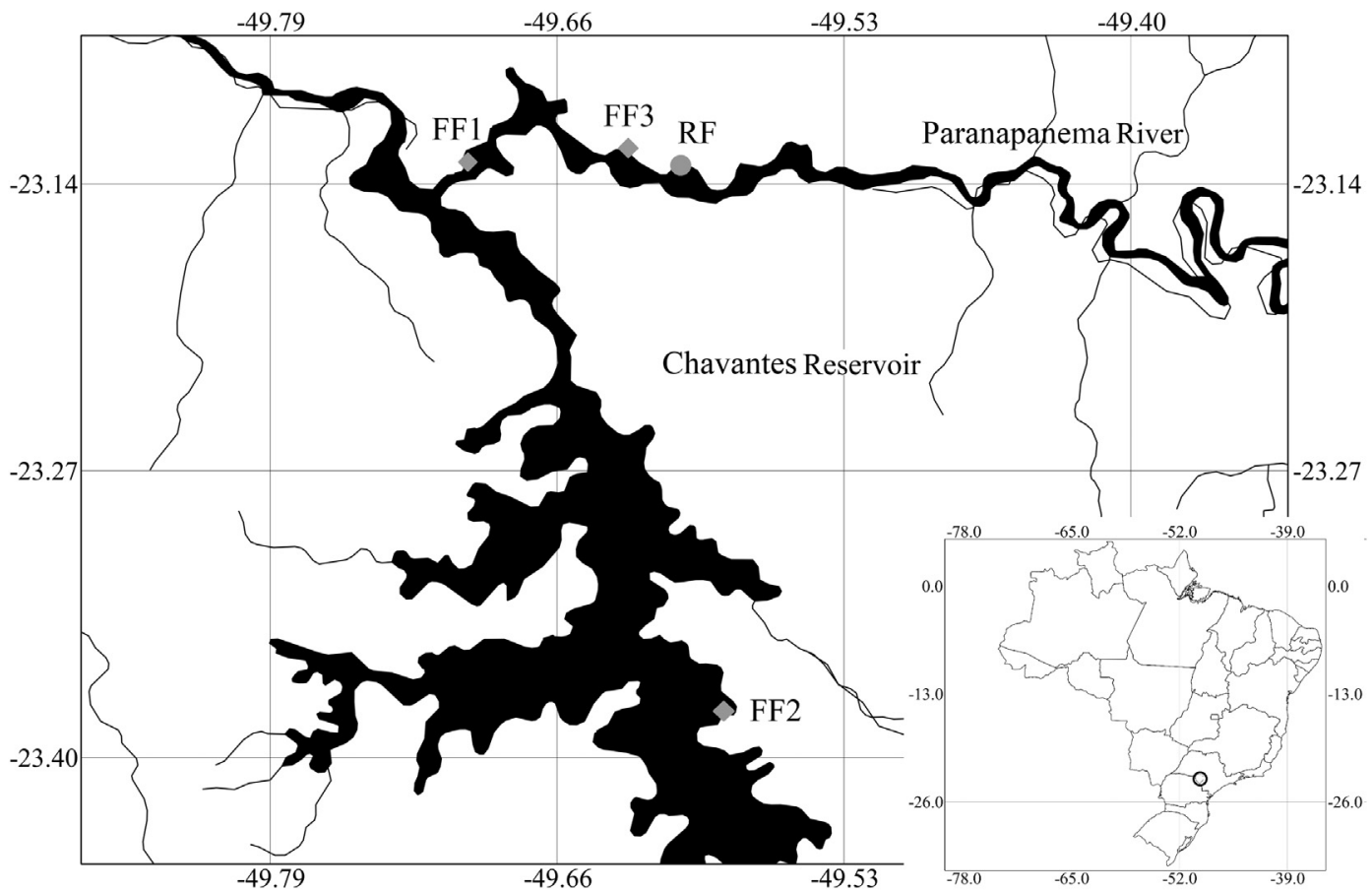

Fig. 1. Map of Brazil. The Chavantes Reservoir (Southeast Brazil) is highlighted, showing the locations of the study areas (RF1 = reference site 1; FF1 = fish farm 1; $\mathrm{RF} 2=$ reference site $2 ; \mathrm{FF} 2=$ fish farm 2; RF3 = reference site 3; FF3 = fish farm 3).

Table 1

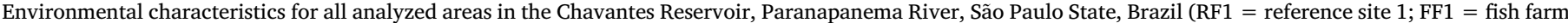
1; RF2 = reference site 2 ; FF2 = fish farm 2; RF3 = reference site 3 ; FF3 = fish farm 3).

\begin{tabular}{|c|c|c|c|c|c|c|}
\hline Characteristics & Fish farm 1 (FF1) & Reference site 1 (RF1) & Fish farm 2 (FF2) & Reference site 2 (RF2) & Fish farm 3 (FF3) & Reference site 3 (RF3) \\
\hline Cage quantity & 500 & 0 & 200 & 0 & 200 & 0 \\
\hline Cage capacity (m3) & 18 & 0 & 18 & 0 & $6-18$ & 0 \\
\hline Maximum depth (m) & 14 & 20 & 43 & 48 & 30 & 25 \\
\hline Sediment type & sandy & sandy & rocky & sandy & rocky & rocky \\
\hline Macrophytes & present & present & absent & present & absent & absent \\
\hline \multirow[t]{2}{*}{ Coordinates } & $23^{\circ} 7^{\prime} 48.6^{\prime \prime} \mathrm{S}$ & $23^{\circ} 8^{\prime} 24.25^{\prime \prime} \mathrm{S}$ & $23^{\circ} 22^{\prime} 42.01^{\prime \prime} \mathrm{S}$ & $23^{\circ} 22^{\prime} 10.98^{\prime \prime} \mathrm{S}$ & $23^{\circ} 7^{\prime} 26.50^{\prime \prime S}$ & $23^{\circ} 7^{\prime} 57.53^{\prime \prime S}$ \\
\hline & $49^{\circ} 42^{\prime} 0,4^{\prime \prime} \mathrm{W}$ & $49^{\circ} 40^{\prime} 30.48^{\prime \prime} \mathrm{W}$ & $49^{\circ} 35^{\prime} 4.14^{\prime \prime} \mathrm{W}$ & $49^{\circ} 34^{\prime} 39.12^{\prime \prime} \mathrm{W}$ & $49^{\circ} 37^{\prime} 40.83^{\prime \prime} \mathrm{W}$ & $49^{\circ} 36^{\prime} 14.43^{\prime \prime} \mathrm{W}$ \\
\hline
\end{tabular}
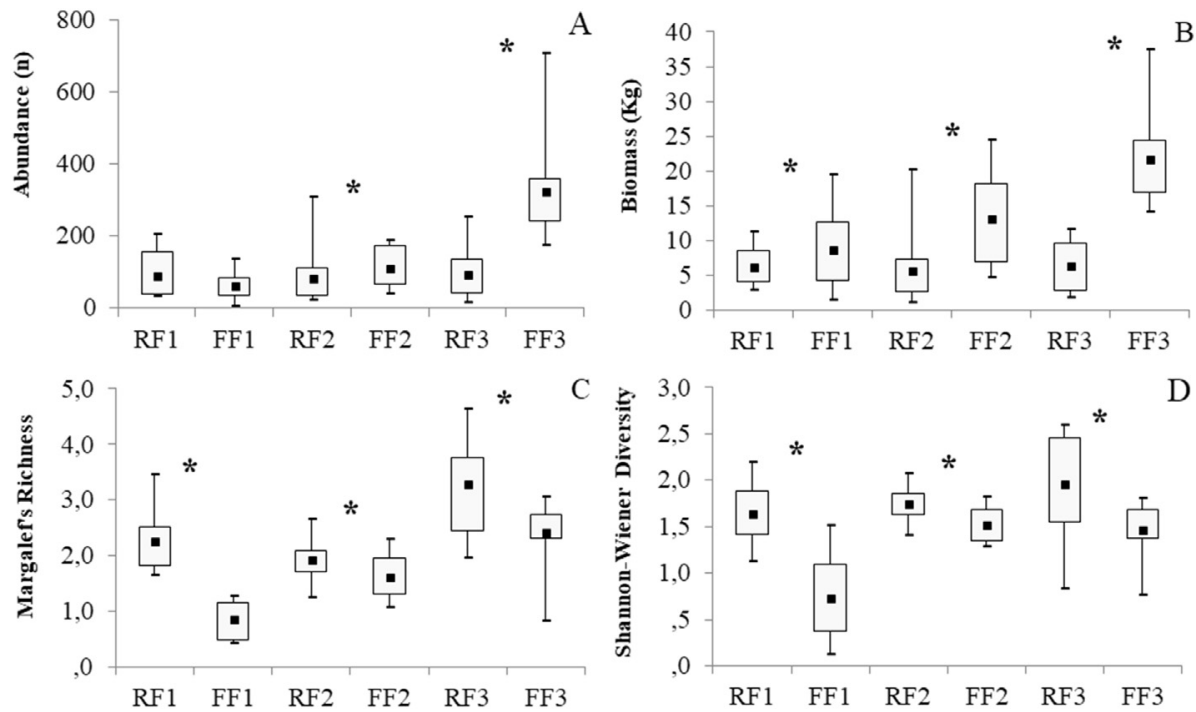

Fig. 2. Ecological attributes for the sampling areas in the Chavantes Reservoir, Paranapanema River, São Paulo State, Brazil (A = Abundance (n); B = Biomass $(\mathrm{Kg}) ; \quad$ Margalef's Richness; $\mathrm{D}=$ Shannon-Wiener Diversity) $(\mathrm{RF} 1=$ reference site 1 ; FF1 = fish farm 1 ; $\mathrm{RF} 2=$ reference site $2 ; \quad \mathrm{FF} 2=$ fish farm 2; $\mathrm{RF} 3=$ reference site 3 ; FF3 = fish farm 3$) *$ indicates significant differences.

\section{Sample areas}




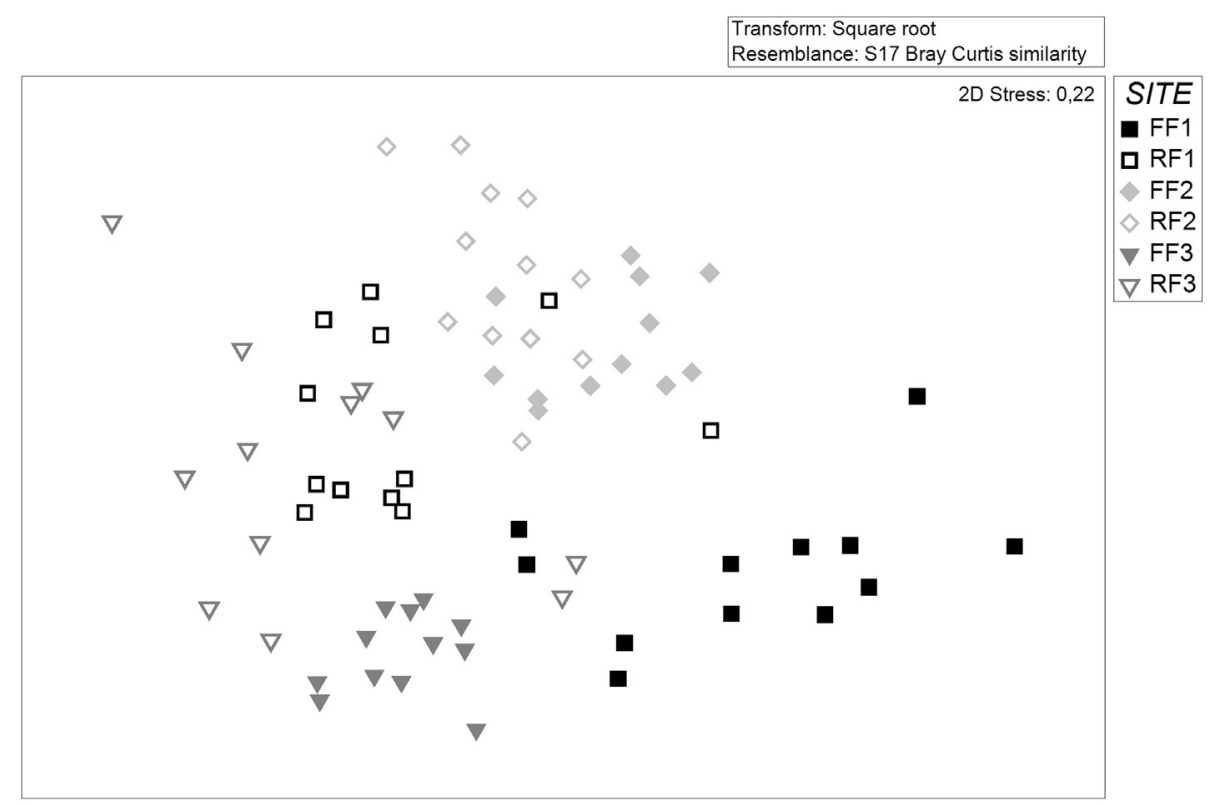

Fig. 3. Multidimensional scaling (MDS) for the fish farms and respective reference sites, for Chavantes Reservoir, Paranapanema River, São Paulo State, Brazil.

Table 2

Similarity percentages (SIMPER) of abundances for the fish farms and reference sites (RF1 = reference site 1; FF1 = fish farm 1; RF2 = reference site 2; FF2 = fish farm 2; RF3 = reference site 3; FF3 = fish farm 3) for the Chavantes Reservoir, Paranapanema River, São Paulo State, Brazil. Cut was done in 50\% of the contribution. In bold, two species that most contribute to dissimilarity in each sampling site.

\begin{tabular}{|c|c|c|c|c|c|c|c|c|c|c|}
\hline \multirow[t]{2}{*}{ Species } & \multirow[t]{2}{*}{ Trophic guild } & \multicolumn{2}{|c|}{ Av.Abund } & \multirow[t]{2}{*}{ Contrib\% } & \multicolumn{2}{|c|}{ Av.Abund } & \multirow[t]{2}{*}{ Contrib\% } & \multicolumn{2}{|c|}{ Av.Abund } & \multirow[t]{2}{*}{ Contrib\% } \\
\hline & & FF1 & RF1 & & FF1 & RF2 & & FF1 & RF3 & \\
\hline & Average dissimilarity & \multicolumn{2}{|c|}{$62.33 \%$} & & \multicolumn{2}{|c|}{64.03} & & \multicolumn{2}{|c|}{$66.75 \%$} & \\
\hline Apareiodon affinis & Detritivore & 1.97 & 5.62 & 19.04 & 1.97 & 2.45 & 11.48 & 1.97 & 5.27 & 15.67 \\
\hline Pimelodus maculatus & Omnivore & 6.06 & 2.44 & 17.48 & 6.06 & 3.4 & 15.55 & 6.06 & 1.97 & 15.59 \\
\hline Galeocharax knerii & Carnivore & & & & & & & & & \\
\hline Iheringichthys labrosus & Omnivore & & & & 0.24 & 2.76 & 10.88 & & & \\
\hline Astyanax lacustris & Omnivore & 0.79 & 2.01 & 7.61 & & & & 0.79 & 2.44 & 6.41 \\
\hline Leporinus amblyrhynchus & Herbivore & & & & & & & 0.35 & 1.45 & 5.29 \\
\hline Plagioscion squamosissimus & Carnivore & 1.05 & 3.42 & 11.24 & & & & 1.05 & 2.47 & 5.23 \\
\hline Schizodon nasutus & Herbivore & & & & & & & 0.2 & 1.53 & 4.87 \\
\hline \multirow[t]{3}{*}{ Steindachnerina insculpta } & Detritivore & & & & 0 & 4.73 & 20.55 & & & \\
\hline & & FF2 & RF1 & & FF2 & RF2 & & FF2 & RF3 & \\
\hline & Average dissimilarity & \multicolumn{2}{|c|}{$54.88 \%$} & & \multicolumn{2}{|c|}{$41.86 \%$} & & \multicolumn{2}{|c|}{$61.34 \%$} & \\
\hline Apareiodon affinis & Detritivore & 1.91 & 5.62 & 14.37 & 1.91 & 2.45 & 8.12 & 1.91 & 5.27 & 12.2 \\
\hline Pimelodus maculatus & Omnivore & 6.08 & 2.44 & 13.9 & 6.08 & 3.4 & 15.34 & 6.08 & 1.97 & 12.52 \\
\hline Galeocharax knerii & Carnivore & & & & & & & & & \\
\hline Iheringichthys labrosus & Omnivore & 3.87 & 1.28 & 10.41 & 3.87 & 2.76 & 10.7 & 3.87 & 1.2 & 8.93 \\
\hline Astyanax lacustris & Omnivore & & & & 1.49 & 1.44 & 8.53 & 1.49 & 2.44 & 4.68 \\
\hline Leporinus amblyrhynchus & Herbivore & & & & & & & & & \\
\hline Plagioscion squamosissimus & Carnivore & & & & & & & & & \\
\hline Schizodon nasutus & Herbivore & & & & & & & & & \\
\hline \multirow[t]{3}{*}{ Steindachnerina insculpta } & Detritivore & 4.96 & 1.38 & 13.31 & 4.96 & 4.73 & 11.65 & 4.96 & 1.14 & 11.85 \\
\hline & & FF3 & RF1 & & FF3 & RF2 & & FF3 & RF3 & \\
\hline & Average dissimilarity & \multicolumn{2}{|c|}{$53.50 \%$} & & \multicolumn{2}{|c|}{$61.71 \%$} & & \multicolumn{2}{|c|}{$52.28 \%$} & \\
\hline Apareiodon affinis & Detritivore & 12.7 & 5.62 & 19.69 & 12.7 & 2.45 & 23.78 & 12.7 & 5.27 & 20.58 \\
\hline Pimelodus maculatus & Omnivore & 8.27 & 2.44 & 15.64 & 8.27 & 3.4 & 11.83 & 8.27 & 1.97 & 16.21 \\
\hline Galeocharax knerii & Carnivore & 5.05 & 1.8 & 8.89 & 5.05 & 0.7 & 10.41 & 5.05 & 1.9 & 8.37 \\
\hline Iheringichthys labrosus & Omnivore & & & & & & & 2.85 & 1.2 & 4.32 \\
\hline Astyanax lacustris & Omnivore & 3.34 & 2.01 & 6.4 & & & & 3.34 & 2.44 & 4.29 \\
\hline Leporinus amblyrhynchus & Herbivore & & & & & & & & & \\
\hline Plagioscion squamosissimus & Carnivore & & & & & & & & & \\
\hline Schizodon nasutus & Herbivore & & & & & & & & & \\
\hline Steindachnerina insculpta & Detritivore & & & & 0.65 & 4.73 & 9.39 & & & \\
\hline
\end{tabular}

groups, one composed by fish farms and another by reference sites (Fig. 3).

The differences between sample areas were mainly due to a small group of fish species, according SIMPER analysis. In general, the dissimilarity for abundance between areas were greater than $50 \%$ in all analyzed areas, considering the two species that most contribute to dissimilarity, we had only five species. Of them, two are omnivoreopportunistic (species that consume all available items) Astyanax lacustris (early A. altiparanae) and Pimelodus maculatus, two are detritivore (species that consume detritus on sediment or other surfaces) Apareiodon affinis and Steindachnerina insculpta and one is carnivore Plagioscion squamosissimus (Table 2). It's possible infer that $P$. maculatus, 
A. affinis and S. insculpta were farm-associated, being they are the species that had higher average abundance in all fish farm analyzed (Table 2).

\section{Discussion}

A large aggregation of native fish fauna around cage fish farm were observed in this study, similar to previous findings in marine (Dempster and Sanchez-Jerez, 2004; Dempster et al., 2002; Özgül and Angel, 2013; Šegvić Bubić et al., 2011) and freshwater environments (Brandão et al., 2013; Brandão et al., 2012; Ramos et al., 2013). In these studies, fish aggregation around cages are mainly modulated by the high quantity of release alimentary resources (Demétrio et al., 2012; Ramos et al., 2008; Uglem et al., 2014), that are consumed for a few fish species (Brandão et al., 2012; Demétrio et al., 2012; Felsing et al., 2005; Ramos et al., 2013; Strictar-Pereira et al., 2010; Vita et al., 2004), contributing to improve its abundance and biomass around these areas as verified in this study.

Our results support that the favoring of few species around cage fish farms, contribute to spatial differences in fish community between fish farm and reference sites, as demonstrated by Permanova analysis. This favoring is supported by concomitantly studies performed in the same cage fish farms with the same fishes used in this study showed that opportunistic and omnivore species, like A. affinis, A. lacustris, I. labrosus, $P$. maculatus and $S$. insculpta consume the uneaten food released by fish farms, causing alterations in their numeric abundance, condition factor and reproductive period (Brandão et al., 2014; Brandão et al., 2013; Brandão et al., 2012; Ramos et al., 2013).

However, differences in fish community structure between seasons were not observed in our results. Some studies performed in the Neotropical region achieve the same results, without seasonal variation (Borges et al., 2010; Miranda et al., 2016). In a storage dam, like Chavantes Reservoir, the large amount of stored water $\left(9410 \times 106 \mathrm{~m}^{3}\right)$ and time of residence of water (352 days) (Montanhini et al., 2015), makes the environment more stable and less suitable for changings along the year (Fantin-Cruz et al., 2016). Thereby, the expected oscillations that occurs in rivers and smaller dammed areas, are amortized by the large volume of water. Moreover, species present in the dammed area are already adjusted to the environmental conditions, being less susceptible for environmental alterations. Also, the continuous input of food in these areas, can contribute to absence of differences caused by seasonality, once the attraction keeps all the year (Brandão et al., 2012) and fish do not have to migrate to other areas in search of food.

Fish can also be attracted to the cages by shelter against predators, constituting the secondary cause of aggregation (Fréon and Dagorn, 2000; Sanchez-Jerez et al., 2011). Generally, Neotropical reservoirs are poor in habitat diversity, due to the filling process (Agostinho et al., 2007; Araújo et al., 2013). Thus, fish farms can improve habitat complexity of this area (Dempster and Taquet, 2004; Fréon and Dagorn, 2000; Sanchez-Jerez et al., 2011) playing a role of physical protection of adults and juveniles of wild species against predators. Protection made by cages remains all the year while water level oscillation in the Reference Site, contributes to eliminate shelters, being that the fishes have to migrate for other areas. This protection allied with the food resources, that can contribute to increase in some fish populations can lead to secondary effect, when predators are attracted for the prey aggregation (Machias et al., 2004; Serra-Llinares et al., 2013). This fact was observed in this study, where Galeocharax knerii (piscivore) are abundant in the fish farms. Previous works showed that $G$. knerii prey $A$. affinis in the vicinity of the cage fish farms (Brandão et al., 2013; Ramos et al., 2013).

Anthropogenic disturbs, as cage fish farm, can increase the stress of the fish community by the presence of physical structure (cages), intense boat movement and attraction of fishermen, contributing to improve the dominance of a few opportunistic species (Felsing et al.,
2005; Machias et al., 2005; Machias et al., 2004). In this study, we observed the same pattern, with few species, $P$. maculatus (omnivore), $A$. affinis and $S$. insculpta (detritivore), dominating the environments under influence of cage fish farm by SIMPER analysis. Generally, only trophic generalists can use the wastes provided by fish farming activity because they show trophic plasticity and rapidly adjust to the new conditions (Gerking, 1994) and, as mentioned above, in the study area, this species consumes the food resources released by cage fish farm, taking advantage over the others (Brandão et al., 2014; Brandão et al., 2013; Brandão et al., 2012; Ramos et al., 2013).

The large aggregation of few fish species around cage farms, can lead to alterations in the diversity indices, as observed in this study for Margalef Richness and Shannon-Wiener Diversity, which had higher values in the reference site in all analyzed areas. The dominance of a few species, can lead to an instability in the homeostasis of environment, leading to a homogenization process, with the simplification of fish community, a worldwide process, that have accentuated in the last years (Magurran et al., 2015; Toussaint et al., 2016). This process is modulated by human's activities, mainly habitat alteration and fish introduction, both related to aquaculture activities. These few species, can obtain advantageous in the interspecific competition with other of the same trophic guild, depleting their populations. Also, some studies, has shown that in the fish farm areas, species that can use the food resource have higher values of the gonadosomatic index (GSi) in relation of the control sites, taking more advantageous in reproductive aspects (Brandão et al., 2014; Brandão et al., 2013; Brandão et al., 2012).

Based on the obtained results, we can infer that the freshwater cage fish farm activity act as a driver of changes in wild fish community, with few species as $P$. maculatus, $A$. affinis and $S$. insculpta being favored. The utilization of this feed can cause modifications to the population's density, which directly affects the structure of the fish fauna assemblage. Thus, cage fish farm activity acts as a community structuring force and can act over the interspecific interactions of the aquatic ecosystem.

Supplementary data to this article can be found online at https:// doi.org/10.1016/j.aquaculture.2018.06.053.

\section{Author's contribution}

This manuscript is derived from two independent projects (Finep Process number 3626/05 and Fapesp Process number 2008/58792-1), of which, among other productions, there were three master's dissertation and four doctoral theses that together gave rise to this work.

ABN: Master's dissertation and preparation of the manuscript.

ASZ: Doctoral thesis and co-responsible for the preparation of the manuscript.

HB: Doctoral thesis and co-responsible for the preparation of the manuscript.

ÉOPZ: Doctoral thesis and participation as a researcher and collaborated in the preparation of the manuscript.

FPL: Data analysis and work discussion.

DFS: Data analysis and work discussion.

EDC: Project's coordinator and advisor in Doctoral thesis and Master's dissertations.

RJ S: Project's coordinator and work discussion.

IPR: Master's dissertation and Doctoral thesis, researcher in the two projects and the scientific manuscript supervisor.

\section{Acknowledgements}

The authors wish to dedicate this work to the memory of Dr. Edmir Daniel Carvalho, Professor, environmentalist and above all, a righteous man who contributed to the personal/professional formation of most of the authors. In addition, we wish to thank Finep (Process number 3626/ 
05) and Fapesp (Process number 2007/58246-4) for financial support, CAPES and CNPq for scholarship, the owners of the fish farms for the opportunity to study and UNESP for infrastructure.

\section{References}

Agostinho, A.A., Pelicice, F.M., Gomes, L.C., 2007. Ecologia e manejo de recursos pesqueiros em reservatórios do Brasil. EDUEM. ed, Maringá.

Agostinho, A.A., Pelicice, F.M., Gomes, L.C., 2008. Dams and the fish fauna of the Neotropical region: impacts and management related to diversity and fisheries. Braz. J. Biol. 68, 1119-1132. http://dx.doi.org/10.1590/S1519-69842008000500019.

Akyol, O., Ertosluk, O., 2010. Fishing near sea-cage farms along the coast of the Turkish Aegean Sea. J. Appl. Ichthyol. 26, 11-15. http://dx.doi.org/10.1111/j.1439-0426. 2009.01348.x.

Araújo, E.S., Marques, E.E., Freitas, I.S., Neuberger, A.L., Fernandes, R., Pelicice, F.M., 2013. Changes in distance decay relationships after river regulation: similarity among fish assemblages in a large Amazonian river. Ecol. Freshw. Fish 22, 543-552. http:// dx.doi.org/10.1111/eff.12054.

Bacher, K., Gordoa, A., Sagué, O., 2012. Spatial and temporal extension of wild fish aggregations at Sparus aurata and Thunnus thynnus farms in the north-western Mediterranean. Aquac. Environ. Interact. 2, 239-252. http://dx.doi.org/10.3354/ aei00042.

Bagdonas, K., Humborstad, O.-B., Løkkeborg, S., 2012. Capture of wild saithe (Pollachius virens) and cod (Gadus morhua) in the vicinity of salmon farms: Three pot types compared. Fish. Res. 134-136, 1-5. http://dx.doi.org/10.1016/j.fishres.2012.06. 020.

Bartozek, E., Bueno, N., Rodrigues, L., 2014. Influence of fish farming in net cages on phytoplankton structure: a case study in a subtropical Brazilian reservoir. Braz. J. Biol. 74, 145-155. http://dx.doi.org/10.1590/1519-6984.21912.

Borges, P.A.F., Train, S., Dias, J.D., Bonecker, C.C., 2010. Effects of fish farming on plankton structure in a Brazilian tropical reservoir. Hydrobiologia 649, 279-291. http://dx.doi.org/10.1007/s10750-010-0271-2.

Brandão, H., Lobón-Cerviá, J., Ramos, I.P., Souto, A.C., Nobile, A.B., de Zica, É.O.P., Carvalho, E.D., 2012. Influence of a cage farming on the population of the fish species Apareiodon affinis (Steindachner, 1879) in the Chavantes reservoir, Paranapanema River SP/PR. Brazil. Acta Limnol. Bras. 24, 438-448. http://dx.doi.org/10.1590/ S2179-975X2013005000012.

Brandão, H., Nobile, A.B., Souto, A.C., Ramos, I.P., de Sousa, J.Q., Carvalho, E.D., 2013. Influence of cage fish farming on the diet and biological attributes of Galeocharax knerii in the Chavantes reservoir. Brazil. Bol. do Inst. Pesca 39, 157-167.

Brandão, H., Santana, J.C.D.O., Ramos, I.P., Carvalho, E.D., 2014. Influence of cage farming on feeding and reproductive aspects of Pimelodus maculatus Lacépéde, 1803 (Siluriformes: Pimelodidae) in the Chavantes reservoir, Brazil. Acta Sci. Biol. Sci. 36. http://dx.doi.org/10.4025/actascibiolsci.v36i1.21039.

Britto, S.G.C., Sirol, R.N., Vianna, N.C., Jardim, S.M., Santos, J.C., Pelisari, E., 2003. Peixes do rio Paranapanema. Editora Horizonte, São Paulo.

Bueno, G.W., Ostrensky, A., Canzi, C., de Matos, F.T., Roubach, R., 2015. Implementation of aquaculture parks in Federal Government waters in Brazil. Rev. Aquac. 7, 1-12. http://dx.doi.org/10.1111/raq.12045.

Clarke, K., Warwick, R., 2001. A further biodiversity index applicable to species lists: variation in taxonomic distinctness. Mar. Ecol. Prog. Ser. 216, 265-278. http://dx. doi.org/10.3354/meps216265.

Demétrio, J.A., Gomes, L.C., Latini, J.D., Agostinho, A.A., 2012. Influence of net cage farming on the diet of associated wild fish in a Neotropical reservoir. Aquaculture 330-333, 172-178. http://dx.doi.org/10.1016/j.aquaculture.2011.11.026.

Dempster, T., Sanchez-Jerez, P., Sempere, J.B., Kingsford, M., 2004. Extensive Aggregations of Wild Fish at Coastal Sea-Cage Fish Farms. Hydrobiologia 525, 245-248. http://dx.doi.org/10.1023/B:HYDR.0000038870.13985.0f.

Dempster, T., Taquet, M., 2004. Fish aggregation device (FAD) research: gaps in current knowledge and future directions for ecological studies. Rev. Fish Biol. Fish. 14, 21-42. http://dx.doi.org/10.1007/s11160-004-3151-x.

Dempster, T., Sanchez-Jerez, P., Bayle-Sempere, J., Giménez-Casalduero, F., Valle, C., 2002. Attraction of wild fish to sea-cage fish farms in the south-western Mediterranean Sea: spatial and short-term temporal variability. Mar. Ecol. Prog. Ser. 242, 237-252. http://dx.doi.org/10.3354/meps242237.

Fantin-Cruz, I., Pedrollo, O., Girard, P., Zeilhofer, P., Hamilton, S.K., 2016. Changes in river water quality caused by a diversion hydropower dam bordering the Pantanal floodplain. Hydrobiologia 768, 223-238. http://dx.doi.org/10.1007/s10750-0152550-4

FAO, 2016. The State of World Fisheries and Aquaculture. FAO - Food and Agriculture Organization of the United Nations, Rome.

Felsing, M., Glencross, B., Telfer, T., 2005. Preliminary study on the effects of exclusion of wild fauna from aquaculture cages in a shallow marine environment. Aquaculture 243, 159-174. http://dx.doi.org/10.1016/j.aquaculture.2004.09.033.

Fréon, P., Dagorn, L., 2000. Review of fish associative behaviour: Toward a generalisation of the meeting point hypothesis. Rev. Fish Biol. Fish. 10, 183-207. http://dx.doi.org/ 10.1023/A:1016666108540.

Gerking, S.D., 1994. Feeding Ecology of Fish. Academic Press, San Diego, California.

Gois, K.S., Pelicice, F.M., Gomes, L.C., Agostinho, A.A., 2015. Invasion of an Amazonian cichlid in the upper Paraná river: facilitation by dams and decline of a phylogenetically related species. Hydrobiologia 746, 401-413. http://dx.doi.org/10.1007/ s10750-014-2061-8.

Graça, W.J., Pavanelli, C.S., 2007. Peixes da planície de inundação do alto rio Paraná e áreas adjacentes. EDUEM, Maringá.

Hammer, Ø., Harper, D.A.T., Ryan, P.D., 2001. Past: paleontological statistics software package for education and data analysis. Palaeontol. Electron. 4, 1-9.
IBGE, 2015. Produção da Pecuária Municipal. Instituto Brasileiro de Geografia e Estatística (IBGE), Rio de Janeiro.

Izquierdo-Gomez, D., González-Silvera, D., Arechavala-López, P., López-Jiménez, J.Á., Bayle-Sempere, J.T., Sánchez-Jerez, P., 2015. Exportation of excess feed from Mediterranean fish farms to local fisheries through different targeted fish species. ICES J. Mar. Sci. 72, 930-938. http://dx.doi.org/10.1093/icesjms/fsu179.

Lima, L.B., Oliveira, F.J.M., Giacomini, H.C., Lima-Junior, D.P., 2016. Expansion of aquaculture parks and the increasing risk of non-native species invasions in Brazil. Rev. Aquac. 1-12. http://dx.doi.org/10.1111/raq.12150.

Loureiro, B.R., Branco, C.W.C., Zaniboni Filho, E., 2011. Influence of net-cage fish farming on zooplankton biomass in the Itá reservoir, SC. Brazil. Acta Limnol. Bras. 23, 357-367. http://dx.doi.org/10.1590/S2179-975X2012005000014.

Machias, A., Karakassis, I., Labropoulou, M., Somarakis, S., Papadopoulou, K., Papaconstantinou, C., 2004. Changes in wild fish assemblages after the establishment of a fish farming zone in an oligotrophic marine ecosystem. Estuar. Coast. Shelf Sci. 60, 771-779. http://dx.doi.org/10.1016/j.ecss.2004.03.014.

Machias, A., Karakassis, I., Giannoulaki, M., Papadopoulou, K., Smith, C., Somarakis, S., 2005. Response of demersal fish communities to the presence of fish farms. Mar. Ecol. Prog. Ser. 288, 241-250. http://dx.doi.org/10.3354/meps288241.

Magurran, A.E., Dornelas, M., Moyes, F., Gotelli, N.J., McGill, B., 2015. Rapid biotic homogenization of marine fish assemblages. Nat. Commun. 6, 8405. http://dx.doi. org/10.1038/ncomms9405.

Menezes, L.C.B., Beyruth, Z., 2003. Impactos da aqüicultura em tanques-rede sobre a comunidade bentônica da represa de Guarapiranga - São Paulo - SP. Bol. Inst. Pesca 29, 77-86.

Miranda, T.O., Lima, H.S., Galon, B., Veronez, A.C., Moretti, M.S., Roper, J.J., Gomes, L.C., 2016. Changes in water quality and the phytoplankton community associated with tilapia cage farming in tropical lakes. Aquat. Living Resour. 29, 403. http://dx. doi.org/10.1051/alr/2016029.

Montanhini, R., Nocko, H., Ostrensky, A., 2015. Environmental characterization and impacts of fish farming in the cascade reservoirs of the Paranapanema river. Brazil. Aquac. Environ. Interact. 6, 255-272. http://dx.doi.org/10.3354/aei00130.

Nobile, A.B., Freitas-Souza, D., Lima, F.P., Bayona-Perez, I.L., de Britto, S.G.C., David, G.S., 2016. Caracterização dos padrões reprodutivos da ictiofauna. In: Silva, R.J. (Ed.), Integridade Ambiental Da Represa de Jurumirim: Ictiofauna e Relações Ecológicas. Editora Unesp, São Paulo, pp. 79-94.

Özgül, A., Angel, D., 2013. Wild fish aggregations around fish farms in the Gulf of Aqaba, Red Sea: implications for fisheries management and conservation. Aquac. Environ. Interact. 4, 135-145. http://dx.doi.org/10.3354/aei00076.

Pelicice, F.M., Vitule, J.R.S., Lima Junior, D.P., Orsi, M.L., Agostinho, A.A., 2014. A serious new threat to brazilian freshwater ecosystems: the naturalization of nonnative fish by decree. Conserv. Lett. 7, 55-60. http://dx.doi.org/10.1111/conl.12029.

Pillay, T.V.R. (Ed.), 2004. Aquaculture and the Environment. Blackwell Publishing Ltd. Oxford, UK. http://dx.doi.org/10.1002/9780470995730.

Price, C., Black, K., Hargrave, B., Morris, J., 2015. Marine cage culture and the environment: effects on water quality and primary production. Aquac. Environ. Interact. 6, 151-174. http://dx.doi.org/10.3354/aei00122.

Ramos, I.P., Vidotto-Magnoni, A.P., Carvalho, E.D., 2008. Influence of cage fish farming on the diet of dominant fish species of a Brazilian reservoir (Tietê River, High Paraná River basin). Acta Limnol. Bras. 20, 245-252.

Ramos, I.P., Brandão, H., Zanatta, A.S., de Zica, É.O.P., da Silva, R.J., de Rezende-Ayroza, D.M.M., Carvalho, E.D., 2013. Interference of cage fish farm on diet, condition factor and numeric abundance on wild fish in a Neotropical reservoir. Aquaculture 414-415, 56-62. http://dx.doi.org/10.1016/j. aquaculture.2013.07.013.

Sanchez-Jerez, P., Fernandez-Jover, D., Uglem, I., Arechavala-Lopez, P., Dempster, Ti, Bayle-Sempere, J.T., Pérez, C.V., Izquierdo, D., Bjørn, P.A., Nilsen, R., 2011. Coastal fish farms as fish aggregation devices (FADs): potential effects on fisheries. In: Bortone, S.A., Brandini, F.P., Fabi, G., Otake, S. (Eds.), Artificial Reefs in Fisheries Management. Taylor \& Francis, Boca Raton, pp. 187-208.

Šegvić Bubić, T., Grubišić, L., Tičina, V., Katavić, I., 2011. Temporal and spatial variability of pelagic wild fish assemblages around Atlantic bluefin tuna Thunnus thynnus farms in the eastern Adriatic Sea. J. Fish Biol. 78, 78-97. http://dx.doi.org/10.1111/ j.1095-8649.2010.02837.x.

Serra-Llinares, R., Nilsen, R., Uglem, I., Arechavala-Lopez, P., Bjørn, P., Noble, C., 2013. Post-escape dispersal of juvenile Atlantic cod Gadus morhua from Norwegian fish farms and their potential for recapture. Aquac. Environ. Interact. 3, 107-116. http:// dx.doi.org/10.3354/aei00051.

Strictar-Pereira, L., Agostinho, A., Gomes, L., 2010. Cage culture with tilapia induces alteration in the diet of natural fish populations: the case of Auchenipterus osteomystax. Braz. J. Biol. 70, 1021-1030. http://dx.doi.org/10.1590/S151969842010000500015.

Tomassetti, P., Gennaro, P., Lattanzi, L., Mercatali, I., Persia, E., Vani, D., Porrello, S., 2016. Benthic community response to sediment organic enrichment by Mediterranean fish farms: case studies. Aquaculture 450, 262-272. http://dx.doi. org /10.1016/j.aquaculture.2015.07.019.

Toussaint, A., Beauchard, O., Oberdorff, T., Brosse, S., Villéger, S., 2016. Worldwide freshwater fish homogenization is driven by a few widespread non-native species. Biol. Invasions 18, 1295-1304. http://dx.doi.org/10.1007/s10530-016-1067-8.

Uglem, I., Karlsen, O., Sanchez-Jerez, P., Saether, B., 2014. Impacts of wild fishes attracted to open-cage salmonid farms in Norway. Aquac. Environ. Interact. 6, 91-103. http://dx.doi.org/10.3354/aei00112.

Vita, R., Marín, A., Madrid, J., Jiménez-Brinquis, B., Cesar, A., Marín-Guirao, L., 2004. Effects of wild fishes on waste exportation from a Mediterranean fish farm. Mar. Ecol. Prog. Ser. 277, 253-261. http://dx.doi.org/10.3354/meps277253.

Zarfl, C., Lumsdon, A.E., Berlekamp, J., Tydecks, L., Tockner, K., 2015. A global boom in hydropower dam construction. Aquat. Sci. 77, 161-170. http://dx.doi.org/10.1007/ s00027-014-0377-0. 